Ann. Biol. anim. Bioch. Biophys., 1978, 18 (4), 991-995.

\title{
In vitro ovulation of European eel (Anguilla anguilla L.) oocytes following in vivo stimulation of sexual maturation
}

par P. EPLER, K. BIENIARZ

Institute of Applied Zoology, Academy of Agriculture 30-059 Krakow, Poland.

Summary. In 27 European female eels, a considerable advance in sexual maturation was induced by HCG and carp hypophyseal homogenate injections although no ovulation followed. In view of this, ovarian samples were taken from 4 females for culture in vitro supplemented with hormones. During 24-hr. incubation, a supplement of HCG + hypophyseal homogenate to the culture medium resulted in 50 p. 100 oocyte ovulation, while addition of prostaglandin or adrenaline induced ovulation in 80 to 90 p. 100 of the oocytes. An attempt to fertilize the ovulated eel oocytes in vitro with fully vital male eel spermatozoa failed to give positive results.

\section{Introduction.}

Studies on artificial reproduction in European eels have been undertaken since the 1930 s, and many attempts were initially made to accelerate sexual maturation in males (Fontaine, 1936), resulting in the obtention of fully mature male eels (Boetius and Boetius, 1967 ; Meske and Cellarius, 1973 ; Bieniarz and Epler, 1977).

A much more difficult problem was to accelerate sexual maturity in femole eels. The first to obtain fully ripe eggs of European eels were Fontaine ef al. (1964), Villani and Lumare (1975), Boetius and Boetius (1976). Attempts to fertilize the eggs, however, proved unsuccessful.

In studies on the acceleration of sexual maturity in European eels undertaken in Poland in 1973, we obtained fully ripe male eels (Bieniarz and Epler, 1977) and a significant increase in the growth of female oocytes (Bieniarz and Epler, 1974).

The aim of this study was to induce ovulation in mature female eels and to obtain offspring of the European eel in artificial conditions. For this purpose, we carried out in vivo studies similar to those of Fontaine et al. (1964), Villani and Lumare (1975) or Boetius and Boetius (1976), as well as investigations in vitro like those done on other species of fish by Yamuchi and Yamamoto (1974) and Jalabert (1976). 


\section{Material and methods.}

We observed 27 females weighing 0.6 to $0.7 \mathrm{~kg}$, placed in aquaria filled with artificial sea water of $30 \mathrm{p} .100$ salinity with 7 to $8 \mathrm{mg} \mathrm{O} / \mathrm{l}$ at 21 to $22{ }^{\circ} \mathrm{C}$. After the fishes had been laboratory-acclimated for 4 days, they were given hormonal injections twice a week containing HCG and carp hypophyseal homogenate (table 1). Hypophyses were collected from 3-year old carp in autumn, fixed in acetone and dried. For in vitro studies, ovarian samples from 4 females were used. Fifteen ovarian samples were taken from each fish killed. Every fragment containing 120 to 150 oocytes 1.0 to $1.1 \mathrm{~mm}$ in diameter was placed in culture medium supplemented with different hormones (table 2).

TABLE 1

Injection of HCG and pituitary carp homogenate in female eels

\begin{tabular}{ccc}
\hline $\begin{array}{c}\text { Days of } \\
\text { investigation }\end{array}$ & $\begin{array}{c}\text { HCG } \\
\text { (kg body weight) }\end{array}$ & $\begin{array}{c}\text { Carp hypophyseal } \\
\text { homogenate } \\
\text { (mg/kg body weight) }\end{array}$ \\
\hline 1 & 250 & - \\
$4-22$ & 500 & - \\
$23-26$ & 500 & 2 \\
$27-30$ & 500 & 3 \\
$31-33$ & 500 & 4 \\
$34-37$ & 500 & 5 \\
38 & 500 & \\
\hline
\end{tabular}

TABLE 2

Percentage of ovulated oocytes of European eels after 24-hour incubation in vitro

\begin{tabular}{|c|c|c|c|c|}
\hline Hormone & female 1 & female 2 & female 3 & female 4 \\
\hline Estriol.......... & + & - & $-1-$ & + \\
\hline Estron. . . . . . . . & -1 & - & + & + \\
\hline Estradiol $\ldots \ldots \ldots$ & + & - & $\div$ & + \\
\hline Testosterone ...... & + & - & t & + \\
\hline Progesterone ..... & + & - & + & + \\
\hline Corticosterone .... & + & - & t- & + \\
\hline DOC $\ldots \ldots \ldots \ldots$ & $f-$ & - & $-1-$ & + \\
\hline DOCA $\ldots \ldots \ldots \ldots$ & + & - & + & + \\
\hline Cortisone.......... & + & 一 & + & + \\
\hline HCG $\ldots \ldots \ldots \ldots$ & t- & - & + & + \\
\hline Carp hypophysis... & $t-$ & $\begin{array}{l}\text { merging of } \\
\text { fatty balls }\end{array}$ & + & + \\
\hline Carp hypophysis & $t-t$ & merging of & $+t$ & $+t$ \\
\hline Prostaglandin .... & $t-t-t$ & + & +++ & +++ \\
\hline $\begin{array}{l}\text { Adrenaline } \ldots \ldots \ldots \\
\text { Control } \ldots \ldots \ldots \ldots\end{array}$ & $\begin{array}{c}+++ \\
+\end{array}$ & \pm & $\frac{t+t}{t}$ & $\frac{t+t}{+}$ \\
\hline
\end{tabular}

+ Single ovulating oocytes.

++ About 50 p. 100 ovulating oocytes.

+++ About $80-90$ p. 100 ovulating oocytes. 


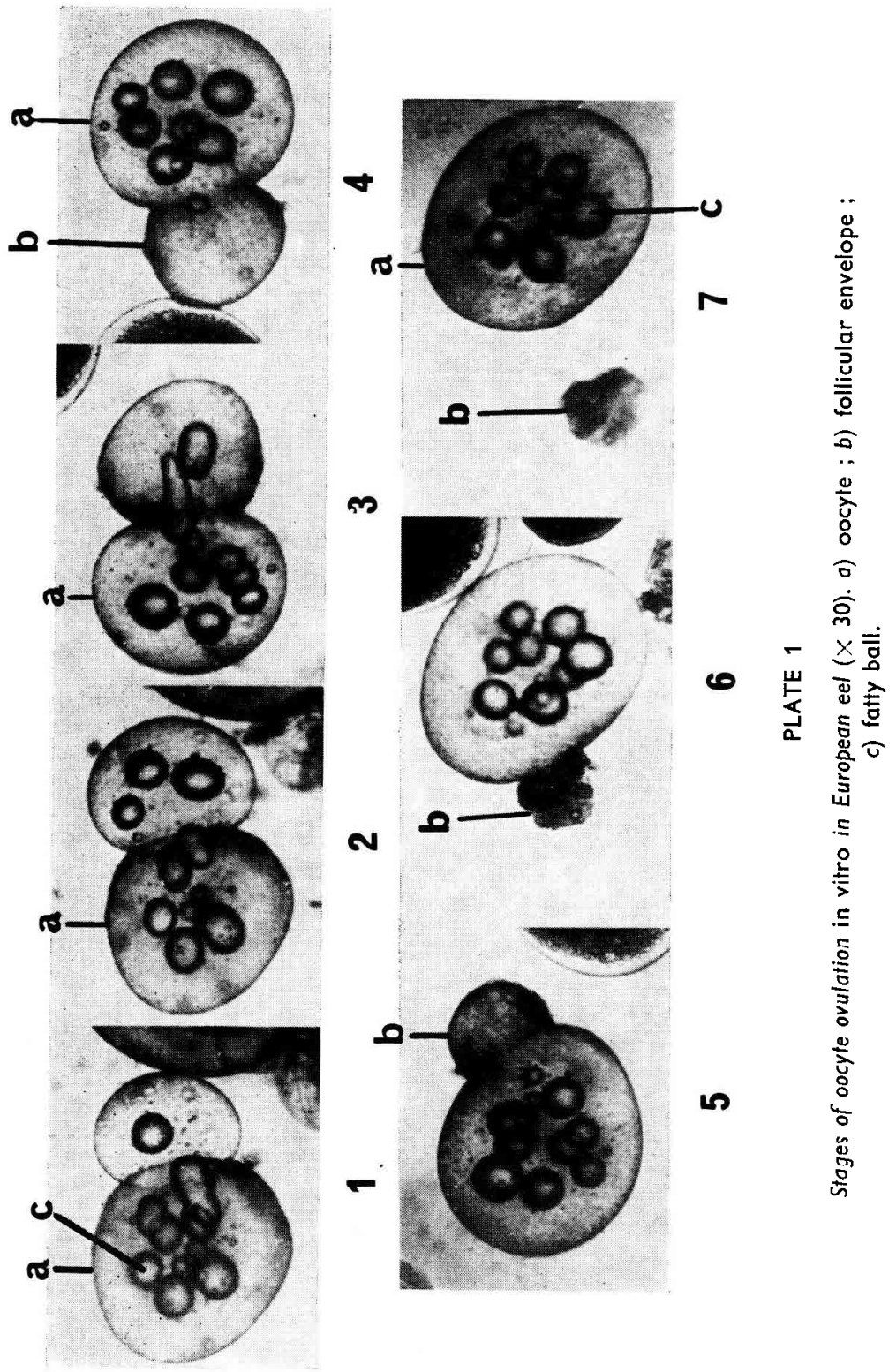


The in vitro oocytes were incubated in BSS Cortland supplemented with 0.3 p. 100 $\mathrm{NaCl}$ (Wolf and Quimby, 1969) at 18 to $20^{\circ} \mathrm{C}$ for $24 \mathrm{hrs}$. Except for the control, this medium was supplemented separately with the hormones (table 2) in the following concentration : steroids $1 \mu \mathrm{g} / \mathrm{ml}$, HCG $100 \mathrm{IU} / \mathrm{ml}$, adrenaline $5 \mu \mathrm{g} / \mathrm{ml}$; prostaglandin $\mathrm{F}_{2 \alpha} 3 \mu \mathrm{g} / \mathrm{ml}$, carp hypophyseal homogenate $100 \mu \mathrm{g}+\mathrm{HCG} 100 \mathrm{lU} / \mathrm{ml}$ of medium.

\section{Results and discussion.}

Since the injections failed to induce ovulation in females, 4 of them were killed ; oocytes of various sizes were found in their ovaries. The largest of these $(1.0$ to $1.1 \mathrm{~mm}$ in diameter) were transparent and 60 p. 100 were lacking the germinal vesicle, while the germinal vesicle in $40 \mathrm{p} .100$ had shifted towards the periphery. These oocytes also presented a fatty ball consisting of a single big ball or a few smaller ones grouped together.

Following 24-hr. incubation in vitro individual ovulating oocytes were found in the control fish as well as in the presence of steroids, HCG or carp hypophyseal homogenate ; 50 p. 100 of ovulating oocytes were found to occur in the presence of carp hypophyseal homogenate + HCG, while 80 to 90 p. 100 of ovulating oocytes were ascertained in the presence of adrenaline or prostaglandin $F_{2 \alpha}$ in the medium (table 2). This result was typical of the cocytes in females Nos. 1, 3 and 4, whereas the oocytes obtained from female No 2 ovulated individually only after treatment with prostaglandin $F_{2 \alpha}$ or adrenaline. The oocytes placed in media supplemented with the other hormones, or in the control, failed to ovulate. However, in the oocytes placed in the media supplemented with carp hypophyseal homogenate $+\mathrm{HCG}$, fatty ball fusion was observed.

In the ovulation process of eel oocytes in vitro (plate I), the oocyte is expulsed through the follicular envelope surrounded by the zona radiata alone. During this time, the follicular envelope rolls up, contracts and falls off after the ovulation process has been completed. An attempt to fertilize the ovulated eel oocytes in vitro with fully vital spermatozoa of male eel, failed to give positive results. No embryonic development was observed.

Our studies seem to indicate that prostaglandin or adrenaline plays a significant role in inducing ovulation in eel oocytes as some other authors found for trout oocytes (Jalabert, 1976). The results also suggest that gonadotropin is directly or indirectly involved in the ovulation process, although a synergistic mechanism of the activity of carp hypophyseal homogenate + HCG is not elucidated.

Symposium sur la Reproduction des Poissons Paimpont, France, 19-21 septembre 1977.

Résumé. Chez des anguilles européennes traitées par un mélange d'HCG et d'extrait hypophysaire total de carpe, la maturation des ovaires est stimulée ; l'ovulation ne se produit pas spontanément. Celle-ci peut être provoquée in vitro par culture de fragments ovariens en présence d'hormones. Après $24 \mathrm{~h}$ d'incubation, l'addition d'HCG et de poudre hypophysaire au milieu de culture entraîne l'ovulation de 50 p. 100 des ovocytes ; l'addition de prostaglandine ou d'adrénaline induit l'ovulation de 80 à 90 p. 100 des ovocytes. Les œufs ovulés obtenus après culture ne sont pas fécondables in vitro. 


\section{References}

BIENIARZ K., EPLER P., 1974. Efudes sur l'accélération de la maturation sexuelle des anguilles en aquarium (en Polonais). Gosp. Ryb., 2, 14-16.

BIENIARZ K., EPLER P., 1977. Investigations on inducing maturity in the male eel (Anguilla anguilla L.) J. Fish Biol., 10, 555-559.

BOETIUS I., BOETIUS J., 1967. Studies in the European eel (Anguilla anguilla L.). Experimental induction of male sexual cycle, its relation to temperature and other factors. Meddel. dan. Fisk. Havunders, 4, 339-405.

BOETIUS I., BOETIUS J., 1976. Estimate of an energy budget for migration and spawning of female European eels. ICES/EIFAC Symp. eel Res. Manag., No 55.

FONTAINE M., 1936. Sur la maturation des organes de l'anguille mâle et l'émission spontanée de ses produits sexuels. C. R. Acad. Sci. Paris, 202, 1312-1314.

FONTAINE M., BERTRAND E., LOPEZ E., CALLAMAND O., 1964. Sur la maturation des organes génitaux de l'anguille femelle (Anguilla anguilla L.) et l'émission spontanée des œufs en aquarium. C. R. Acad. Sci. Paris, 259, 2907-2910.

JALABERT B., 1976. In vifro maturation and ovulation in rainbow trout (Salmo gairdneri L.), northern pike (Esox lucius) and goldfish (Carassius auratus L.). J. Fish. Res. Boord Can., 33, 974-988.

MESKE C., CELLARIUS O., 1973. Experimental erzeugte Geschlechtsreife und Beobachtungen zur Sexualdifferenzierung bei Aalen (Anguilla anguilla L.) in Warmwasserhalłung. Arch. Fischwiss., 1-3, 191-197.

VILLANI P., LUMARE F., 1975. Nota sullacerescimento ovarico in Anguilla anguilla L. Invest. Pesq., 39, $187-197$.

WOLF K., QUIMBY M. C., 1969. Fish cell and tissue culture, 253-301. In HOAR W. S., RANDALL D. J., Fish physiology, Acad. Press, N. York.

YAMUCHI K., YAMAMOTO K., 1974. In vitro maturation of Japanese eel eggs and early development of the eggs. Bull. jap. Soc. Sci. Fish., 40, 153-157. 